\title{
P-element-mediated enhancer detection: an efficient method for isolating and characterizing developmentally regulated genes in Drosophila
}

\author{
Clive Wilson, Rebecca Kurth Pearson, Hugo J. Bellen, ${ }^{1}$ Cahir J. O'Kane, ${ }^{2}$ Ueli Grossniklaus, and \\ Walter J. Gehring \\ Department of Cell Biology, Biozentrum, University of Basel, $\mathrm{CH}-4056$ Basel, Switzerland
}

\begin{abstract}
We describe a new approach for identifying and studying genes involved in Drosophila development. Single copies of an enhancer detector transposon, $P[1 \mathrm{ArB}]$, have been introduced into flies at many different genomic locations. The $\beta$-galactosidase reporter gene in this construct is influenced by a wide range of genomic transcriptional regulatory elements in its vicinity. Our results suggest that a significant proportion of these regulatory sequences are control elements of nearby Drosophila genes. These genes need not be disrupted for their regulatory elements to be identified by $\mathrm{P}[\mathrm{IArB}]$. The $\mathrm{P}[\mathrm{IArB}]$ transposon has been designed to facilitate both rapid cloning and deletion analysis of genomic sequences into which it inserts. Therefore, the enhancer detection system is an efficient method of screening for genes primarily on the basis of their expression pattern and then rapidly analyzing those of particular interest at the molecular and genetic levels.
\end{abstract}

[Key Words: Development; transcriptional regulation; enhancers; gene detection; mutagenesis; Drosophila]

Received March 24, 1989; revised version accepted July 14, 1989.

To further our understanding of development in higher eukaryotes, it has become increasingly important to isolate and study genes that play a developmental role in these organisms. Techniques designed to screen for such genes must basically fulfill two requirements: (1) They must allow identification of many different genes and preferably give some indication of their role; (2) then should they facilitate cloning of any selected gene that is of particular interest. Because such screening methods have not been established in most eukaryotes, including vertebrates, systematic molecular studies of development have been restricted to a few model nonvertebrate systems.

The fruitfly Drosophila melanogaster is a particularly useful organism in which to study development. A number of features, especially its well-characterized genetics, have allowed many developmentally important genes to be identified and analyzed. Extensive classical genetic screens have been used successfully to identify many genes involved in the early development of Drosophila (Gans et al. 1975; Nüsslein-Volhard and Wieschaus 1980). However, as a general method for identifying developmentally important genes, such screens suffer from two major limitations: (1) Even if a mutation leads to recessive lethality, it may be difficult to assess the function of the gene involved if the mutant embryos

Present addresses: ${ }^{1}$ Institute for Molecular Genetics, Baylor College of Medicine, Houston, Texas 77030 USA.; ${ }^{2}$ Department of Biological Science, University of Warwick, Coventry CV4 7AL, UK. or larvae have no clearly visible morphological defects; (2) it is possible that the function of many genes involved in development may be largely or completely complemented by other genes because of redundancy. The complete absence of a gene may therefore not lead to an obvious phenotype.

In light of the limitations of classical genetic screens, it has been important to devise other approaches to isolate developmental genes. One such method involves screening for gene expression patterns using panels of monoclonal antibodies raised against specific parts or the whole of an organism (e.g., Fujita et al. 1982). Those antibodies that react with antigens expressed in tissues of interest may be used to clone the corresponding gene (e.g., Zipursky et al. 1985). However, this approach frequently is extremely time-consuming, and genes that are cloned are not amenable to an immediate genetic analysis.

In this paper we describe a new and powerful method for rapidly identifying and isolating genes involved in Drosophila development. This uses the recently developed P-element-mediated enhancer detection system (O'Kane and Gehring 1987; Bellen et al. 1989). Enhancer detector transposons are modified $\mathrm{P}$ elements that can detect transcriptional regulatory elements in the Drosophila genome. In these constructs the expression of the Escherichia coli $\beta$-galactosidase gene (lacZ) has been placed under the control of a weak promoter. In integrated copies of the transposon, the lac $Z$ gene acts as 
a reporter for genomic transcriptional enhancer-like elements that lie sufficiently close to the transposon to affect this promoter.

Recently, we performed an extensive enhancer detector screen (see Bellen et al. 1989) with a novel enhancer detector, $\mathrm{P}[\mathrm{AArB}]$, which we describe in this paper. We used a procedure that can generate efficiently many insertion strains (or 'transposants') carrying single copies of the transposon. Remarkably, $\sim 65 \%$ of all transposants express $\beta$-galactosidase in a spatially restricted pattern. Furthermore, the promoter of the $l a c Z$ fusion gene seems to be susceptible to a multitude of tissue-specific and cell-type-specific regulatory elements. Mapping the insertions in some of the transposants by in situ hybridization to chromosomes suggested that at least some of these detected elements control adjacent Drosophila genes. For two of these cases, we confirm this at the molecular level. Also, we investigate a critical question concerning the enhancer detection technique: How many of the detected enhancer-like elements normally regulate Drosophila genes? We demonstrate that in a significant proportion of insertion strains, the regulatory elements identified are responsible for the control of neighboring genes. Therefore, enhancer detection can be used as a powerful screening method for developmentally regulated genes; inserted copies of the $\mathrm{P}[\mathrm{lArB}]$ transposon allow an initial selection of interesting genes in vivo purely on the basis of their spatial and temporal expression. In any selected insertion strain, $\mathrm{P}[\mathrm{lArB}]$ then serves as a tag for the gene (e.g., Bingham et al. 1981) and is designed to facilitate its molecular analysis. Furthermore, in a subsequent mutagenesis experiment it is also straightforward to screen for putative deletions of a newly discovered gene, using either of two marker genes present in $\mathrm{P}[\mathrm{lArB}]$.

In conclusion, enhancer detection can be used to analyze many different genes in Drosophila, including those that cannot be identified or characterized initially by classical genetics. Because an enhancer detector system has been described recently in the mouse (Allen et al. 1988; Gossler et al. 1989), this technique also may have applications in the direct isolation of developmental genes from vertebrates.

\section{Results}

Structure of P-1ArB, a new enhancer detector plasmid

We constructed a new plasmid, P-1ArB, which is more versatile than the original enhancer detector insertion vector pLacA92, described by O'Kane and Gehring (1987) (see Materials and methods; Fig. 1A). Like pLacA92, at the $5^{\prime}$ end of $\mathrm{P}-1 \mathrm{ArB}$, there is a P-1acZ-hsp 70 fusion gene in which the expression of the $E$. coli $\beta$-galactosidase gene is placed under the control of the weak P-transposase promoter. In addition, $\mathrm{P}-1 \mathrm{ArB}$ contains the rosy ${ }^{+}$ $\left(r \mathrm{y}^{+}\right)$and Alcohol dehydrogenase ${ }^{+}\left(A d h^{+}\right)$genes, which may be used to screen for flies carrying the $P$ element. These marker genes also are particularly useful in a genetic analysis of insertion strains (see Discussion).

$\mathrm{P}-\mathrm{lArB}$ is designed to facilitate the molecular analysis of adjacent genomic sequences. Genomic libraries need not be constructed from each transposant to isolate these sequences. A modified form of the plasmid vector Bluescript $\mathrm{M}^{+} 3^{+} \mathrm{KS}$ in the construct allows rapid cloning of DNA adjacent to the $3^{\prime}$ end of the transposon by plasmid rescue (Fig. 1B; Perucho et al. 1980; Pirrotta 1986). In brief, a polylinker, PL3 (see Fig. 1A), contains six different restriction sites that are not found farther $3^{\prime}$ in $\mathrm{P}[\mathrm{ArB}]$. Consequently, digestion of transposant genomic DNA with any of these restriction enzymes, followed by religation in conditions that favor intramolecular reactions, produces replication-proficient plasmids carrying Bluescript sequences and genomic sequences located directly $3^{\prime}$ of the transposon (see Fig. 1B). These 'rescued' clones may be analyzed directly or may be used to initiate a genomic walk. A fragment containing the $3^{\prime}$ P-element sequences and all of the genomic sequences in a clone can almost invariably be generated by digesting with both the enzyme used to rescue the clone and with NotI (see Fig. 1B).

Some $\beta$-galactosidase expression patterns correspond to the known pattern of expression of genes directly adjacent to the enhancer detector

In Bellen et al. (1989), it was demonstrated that the enhancer detector $\mathrm{P}[\mathrm{lArB}]$ identifies a diverse variety of transcriptional regulatory elements in the genome. In at least five insertion strains we found that $\mathrm{P}[\mathrm{LArB}]$ is at the same cytological location as a gene that has a similar pattern of expression to the lac $Z$ gene, suggesting that the Drosophila gene and the reporter gene might be under the control of the same regulatory elements (e.g., see Fig. 1C). Now we describe a more detailed characterization of two of these transposants.

Transposant A109.1F2 carries an insertion on the second chromosome balancer CyO. Staining of A109.1F2 embryos revealed that the fat body and many scattered cells, which are located in different positions in different embryos, express $\beta$-galactosidase from stage 17 onward (Fig. 2A; for staging and description of embryogenesis, see Campos-Ortega and Hartenstein 1985). The scattered cells were thought to be hemocytes, cells found in the hemolymph of embryos. The genomic sequences adjacent to the $3^{\prime}$ end of the $\mathrm{P}[\mathrm{IArB}]$ insertion in this transposant were cloned by plasmid rescue /see Fig. 1B|. The resulting plasmid, pA109.1F2S, was used as a probe to map cytologically the cloned genomic sequences on wild-type polytene chromosomes. These sequences are located at the border between bands 25B and $C$ on the second chromosome, a position at which the collagen type IV gene (Dcg1; Natzle et al. 1982) maps. This gene shares strong homology with mammalian collagen type IV genes (Blumberg et al. 1987; Cecchini et al. 1987). Like the lacZ gene in strain A109.1F2, it is expressed specifically in both the fat body and embryonic hemocytes (Mirre et al. 1988). However, collagen transcripts are observed first $\sim 6 \mathrm{hr}$ before $\beta$-galactosidase staining is detected. We mapped the position of the rescued genomic sequences roughly by Southern 


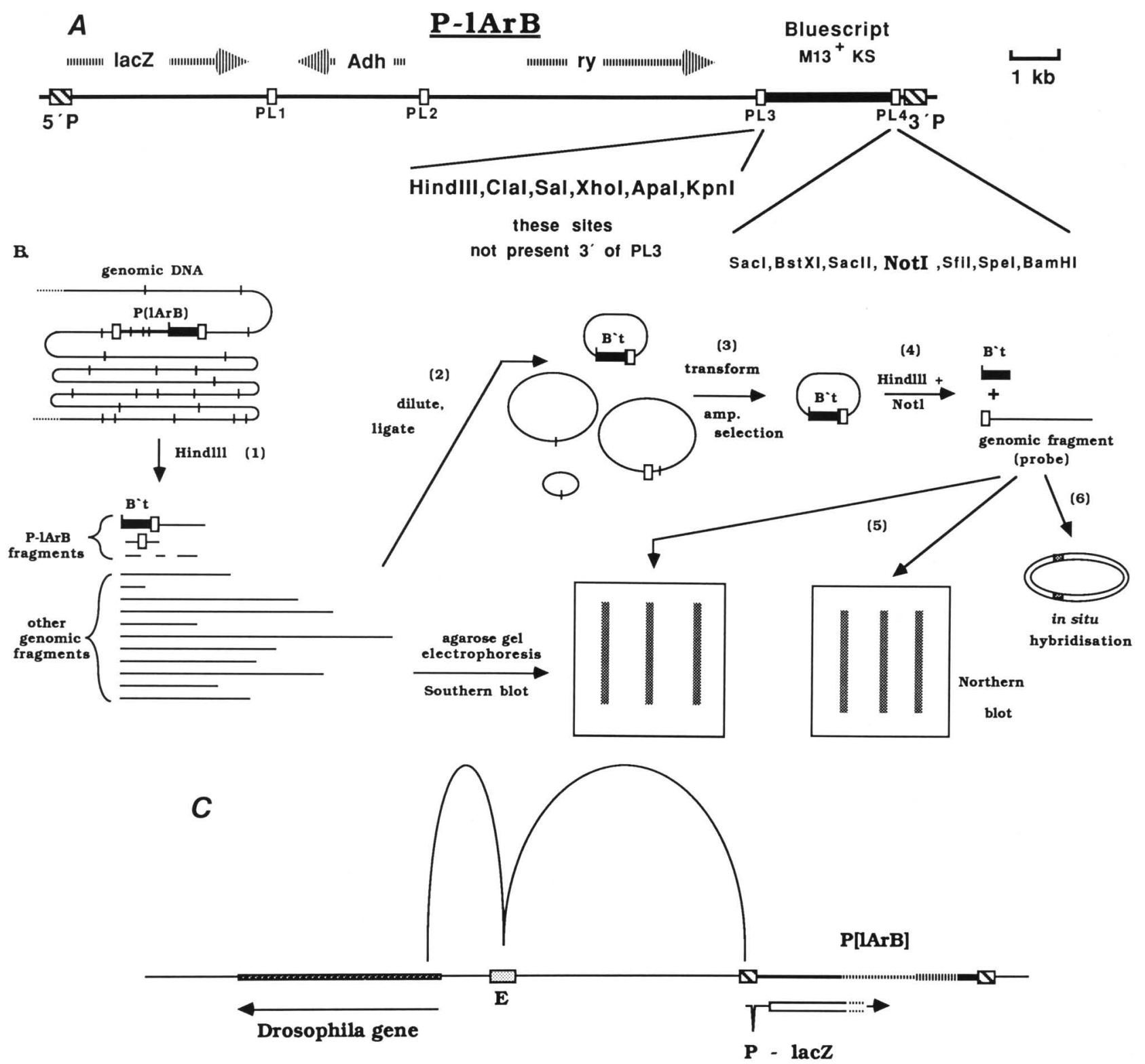

Figure 1. Structure and functions of the P-element enhancer detector, $\mathrm{P}[\mathrm{lArB} \mid$. $(A)$ Structure of the P-lArB plasmid. The key features of P-lArB are shown. They contain the P-lacZ fusion gene from pLacA92 lan in-frame translational fusion of the $E$. coli lac $Z$ gene to coding sequence in the second exon of the P-transposase gene $\left(\mathrm{O}^{\prime}\right.$ Kane and Gehring 1987)], a functional $A d h^{+}$gene, the $r y^{+}$gene as an eye color marker, and Bluescript plasmid sequences (for construction, see Materials and methods). The sequencing primer site of Bluescript is located next to the polylinker PL4. The transposon is flanked by the $5^{\prime}$ and 3' P-element sequences necessary for transposition (hatched boxes). The polylinker PL3 contains six restriction enzyme sites that are not present farther 3 ' in the construct and therefore may be used for plasmid rescue (see text and Fig. 1B). the NotI site in PL4 is unique to the whole construct. All other sites also are found at other unmarked positions in the transposon. $(B)$ Plasmid rescue experiments with P[1ArB $]$. Genomic DNA from a $\mathrm{P}[\mathrm{ArB}]$ transposant is digested first with one of the six enzymes that cut in PL3, in this case HindIII (1). After inactivation of the enzyme and dilution, the genomic fragments are ligated together (2). When this ligation mixture is used to transform competent $E$. coli cells, only those molecules containing Bluescript sequences $\left(B^{\prime} t\right)$ can replicate and confer ampicillin resistance and therefore are rescued (3). Digestion with HindIII (the enzyme used for resuce) and NotI normally produces a fragment containing $3^{\prime}$ P-element sequences and all of the adjacent cloned genomic DNA $(4)_{\text {; Not }}$ recognizes a specific 8-bp sequence and therefore cuts only rarely in the genome. This digestion was used routinely to characterize initially rescued clones. The genomic fragment generated from such a digest of plasmid DNA can be isolated on a gel and labeled as a probe for Southern and Northern analysis (5) or in situ hybridization to embryo sections (6). Examples of such experiments are discussed in the text. $(C)$ Schematic diagrm showing the effect of a genomic regulatory element on $\mathrm{P}[\mathrm{ArB}] . \mathrm{P}[\mathrm{ArB}]$ has inserted near an enhancer element $|E|$, which activates transcription from the $\mathrm{P}$-transposase promoter of the P-lacZ fusion gene (the fused $\beta$-galactosidase-coding sequence is indicated by an open box). In this hypothetical example, the enhancer controls the expression of a neighboring Drosophila gene; therefore, the pattern of $\beta$-galactosidase expression reflects at least part of the expression pattern of this gene. Plasmid rescue followed by a short chromosomal walk allows the cloning of the gene if this pattern is of interest. Many other configurations for genomic insertion of P[lArB] clearly are possible (see, e.g., Fig. 3). 

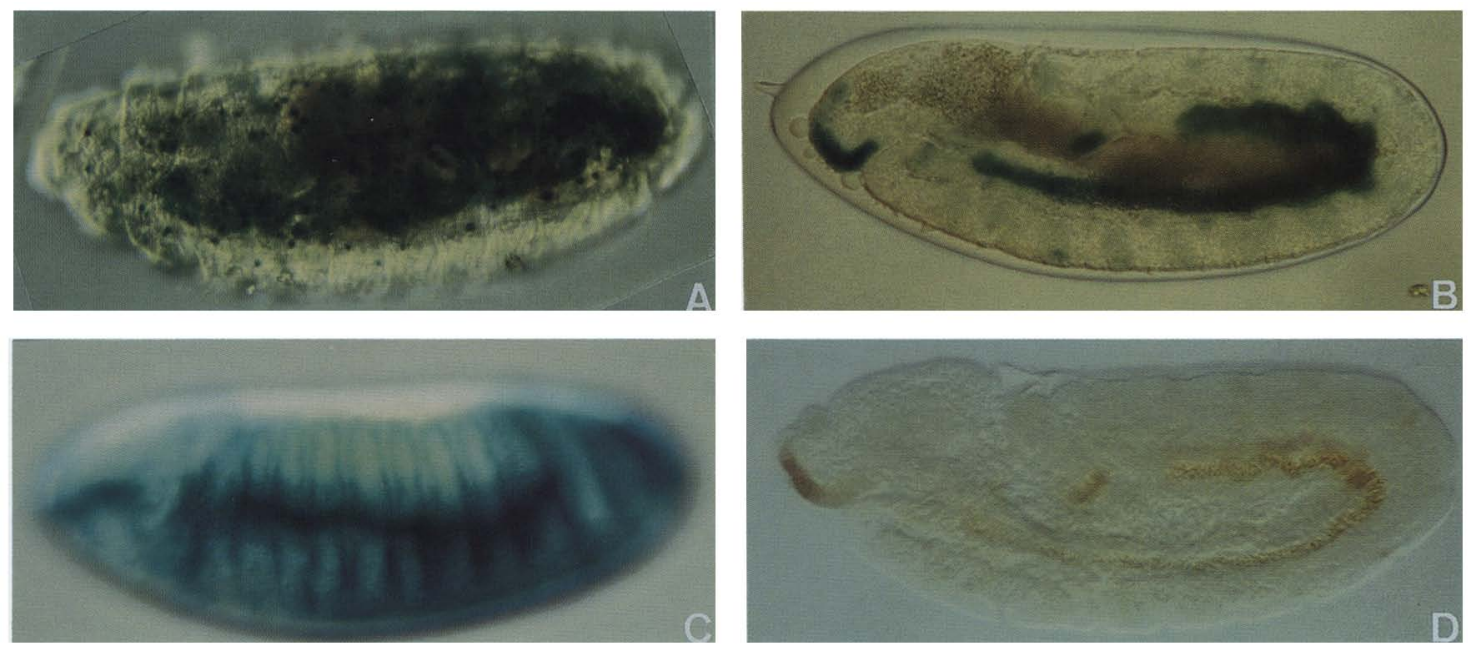

Figure 2. Patterns of $\beta$-galactosidase expression in transposants A109.1F2 and A183.1F2. Whole-mount transposant embryos stained for $\beta$-galactosidase activity $(A, B$, and $C)$. (A) Embryo (16- to 20-hr old; stage 17) from transposant strain A109.1F2. The lacZ gene, like the collagen type IV gene (Mirre et al. 1988), is expressed in the fat body and in scattered cells throughout the embryo, which are thought to be hemocytes. (B) Embryo (7-hr old; stage 11) from transposant strain A183.1F2. $\beta$-Galactosidase is expressed in the clypeolabrum (most anterior), visceral mesoderm (a line of cells extending around the germ band from the cephalic segments to the seventh abdominal segment), the proctodeum (a patch in the center of the embryol, and in a segmentally repeated pattern in the CNS (faint stripes at periphery). This pattern is essentially identical to the immunocytochemical staining pattern of wild-type wholemount embryos using mAb 2D5, which recognizes the fasciclin III protein [(D) (Patel et al. 1987)]. (C) Embryo (10- to 12-hr old; stage 14) from transposant strain Al83.1F2. At this later stage, $\beta$-galactosidase, like fasciclin $I I I$, is expressed in the epidermis in segmentally repeated stripes (cf. Fig. 3B in Patel et al. 1987).

analysis of clones delimiting the entire collagen type $\mathrm{IV}$ gene (Dcg1 and Dcg24; Le Parco et al. 1986). A subsequent comparison of the restriction map and sequence of pA109.1F2S with the known map and sequence of the collagen type IV gene (Blumberg et al. 1988; B. Blumberg and A. MacKrell, pers. comm.) revealed that the site of insertion is $\sim 45$ bp upstream of the putative transcription start site (see Fig. 3A).

A second transposant, A183.1F2, which also carries an insertion on the second chromosome $C y O$, expresses $\beta$ galactosidase in a complex but highly reproducible pattern. Embryos are stained in epidermal cells immediately anterior and posterior to segment boundaries, the visceral mesoderm, the clypeolabrum /the anterior region of the head), the proctodeum, and some cells of the central nervous system (CNS) (see Fig. $2 \mathrm{~B}$ and C). The position of the $\mathrm{P}[\mathrm{lArB}]$ insertion was mapped cytologically using as a probe the subclone pA183.1F2H, which had been isolated from transposant Al 83.1F2 by plasmid rescue. This probe hybridized to wild-type second chromosomes at band $36 \mathrm{E}$, the position of a number of known genes, including the fasciclin III gene. The expression pattern of the protein product of the fasciclin III gene has been reported previously (Patel et al. 1987). Comparison of Figure 2, B and D, demonstrates that this expression pattern, as determined by immunocytochemical staining using mAb 2D5 (Patel et al. 1987; kindly provided by Nipam Patel and Corey Goodman), is essentially identical to the staining pattern in strain A183.1F2.

Flies carrying the $\mathrm{P}[\mathrm{ArB}]$-containing $\mathrm{CyO}$ chromosome of A183.1F2 and a second chromosome with a de- ficiency for the region of insertion are viable and fertile. However, when flies heterozygous for the $\mathrm{P}[\mathrm{lArB}]$-containing $\mathrm{CyO}$ chromosome are mated to each other, there is no detectable immunostaining with the fasciclin III antibody in one-quarter of the embryonic progeny /data not shown). This class of embryos is presumably homozygous for the insertion, suggesting that the fasciclin III gene is disrupted by $\mathrm{P}[\mathrm{lArB}]$ in transposant A183.1F2. To confirm this hypothesis, a Southern analysis was performed with fasciclin III genomic clones /a gift from Peter Snow), and sites for selected restriction enzymes were mapped in plasmid pA183.1F2H. This revealed that the $\mathrm{P}[\mathrm{lArB}]$ insertion lies $\sim 60$ bp upstream of the start of transcription of the fasciclin III gene /see Fig. 3B; the restriction map of the gene was supplied by $P$. Snow, pers. comm.).

\section{Enhancer detectors are influenced frequently by the regulatory elements of genes in their vicinity}

We estimate from the literature that the embryonic expression patterns of $<1 \%$ of all Drosophila genes have been characterized to date. Therefore, our initial search for known genes controlled by the detected regulatory elements could draw from only a very limited sample of candidate genes. We were aware that it was necessary to show that enhancer detectors not only identify the regulatory elements of genes, but that they do so in a significant proportion of transposants. Therefore, we took an alternative and more general approach for identifying appropriately regulated genes that did not require any previous knowledge of the expression pattern of the de- 
A

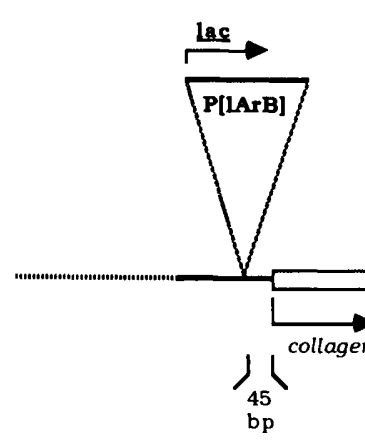

B.
Collagen tupe IV

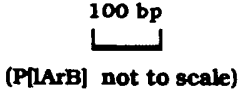

Easciclin $m$

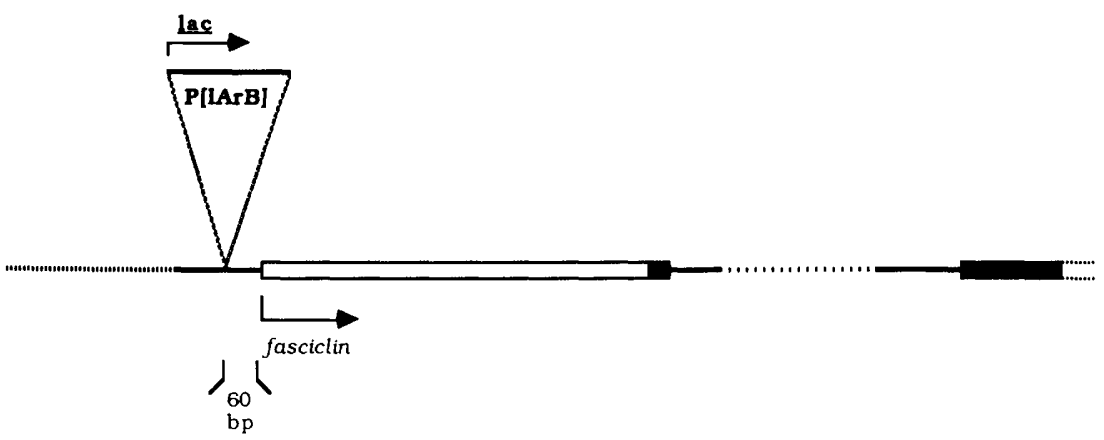

Figure 3. Positions of $\mathrm{P}[\mathrm{AArB}]$ insertions in the collagen type $I V$ and fasciclin $I I I$ genes. $|A| \mathrm{A} 1.5$-kb NotI-SalI genomic fragment from pA109.1F2S (which was rescued with SalI; for details of isolation, see Fig. 1B) was used as a probe for a Southern analysis of clones delimiting the entire collagen type IV gene (Dcg1 and Dcg24; Le Parco et al. 1986). The probe hybridizes to a 3.5-kb HindIIIBamHI fragment of Dcg1 (data not shown). The exact location of the P[lArB] insertion (not drawn to scale) in transposant A109.1F2 was determined by restriction mapping and sequence analysis; it lies $\sim 45$ bp upstream of the putative transcription start site (Blumberg et al. 1988; B. Blumberg and A. MacKrell, pers. comm.). (B) Southern analysis was performed to map the location of the genomic sequences in pA183.1F2H, using two genomic clones containing all but a central portion of the fasciclin III gene (a gift from Peter Snow). The 3.5-kb NotI-HindIII fragment used as a probe hybridized to the $5^{\prime}$ end of the gene (data not shown). The precise location of the $\mathrm{P}[\mathrm{ArB}]$ insertion in transposant A109.IF2 was found by comparison of the restriction maps of the fasciclin III gene (P. Snow, pers. comm.) and the rescued genomic fragment. It lies $\sim 60 \mathrm{bp}$ upstream of the proposed transcription start site. Both insertions are oriented such that the $l a c Z$ gene is transcribed in the same direction as the gene into which P[lArB] inserts. (Open boxes) $5^{\prime}$-Untranslated regions of the Drosophila genes; (solid boxes) coding sequences.

tected gene. Genomic regions lying directly $3^{\prime}$ of the $\mathrm{P}[\mathrm{lArB}]$ insertion in a number of selected strains were cloned and analyzed to determine whether they encoded part of a transcript that was regulated in the expected fashion (scheme summarized in Fig. 1B).

Twenty-eight transposant strains were selected for our analysis. The transposants were chosen because they express $\beta$-galactosidase in a spatially restricted pattern, which includes a sufficiently large and ordered group of cells that the pattern would recognize in thin sections of embryos hybridized to the appropriate nucleic acid probe. Transposants that stain primarily in the head skeleton and trachea were not selected because these structures are obscured frequently by background signals using our in situ hybridization technique. Of the 23 first and third chromosome insertion strains, 17 do not have a readily discernible recessive phenotype; 1 is a recessive female sterile and the other 5 are recessive lethal.

Genomic clones were recovered from 26 of the 28 transposants (see Materials and methods). To confirm that the cloned genomic sequences were situated adja- cent to the $\mathrm{P}[1 \mathrm{ArB}]$ insertion in each transposant, a genomic Southern analysis was performed with preparations of DNA from appropriate fly strains (see Materials and methods). This test revealed that 3 of the 26 genomic probes contained repetitive sequences; these probes were not used for further analysis. Results for all of the remaining 23 probes indicated that they had been generated from genomic sequences adjacent to the $\mathrm{P}[\mathrm{lArB}]$ insertion. Figure $4, \mathrm{~A}$ and $\mathrm{B}$, shows typical examples of genomic Southern blots; the results for two transposants with third chromosome insertions B52.1M3 and A107.1M3 are shown because they will be considered in detail in the following sections.

To test whether any of the cloned genomic regions were part of a transcription unit, all of the probes were used for Northern analysis of poly(A) ${ }^{+}$RNA isolated from embryos at different stages of development. In total, 12 of the 23 probes hybridized to a specific transcript or transcripts. For example, the Northern blots for strains B52.1M3 and A107.1M3 (Fig. 4C and D) indicated that the cloned genomic fragments encode part of a single transcript. Both transcripts are expressed first 


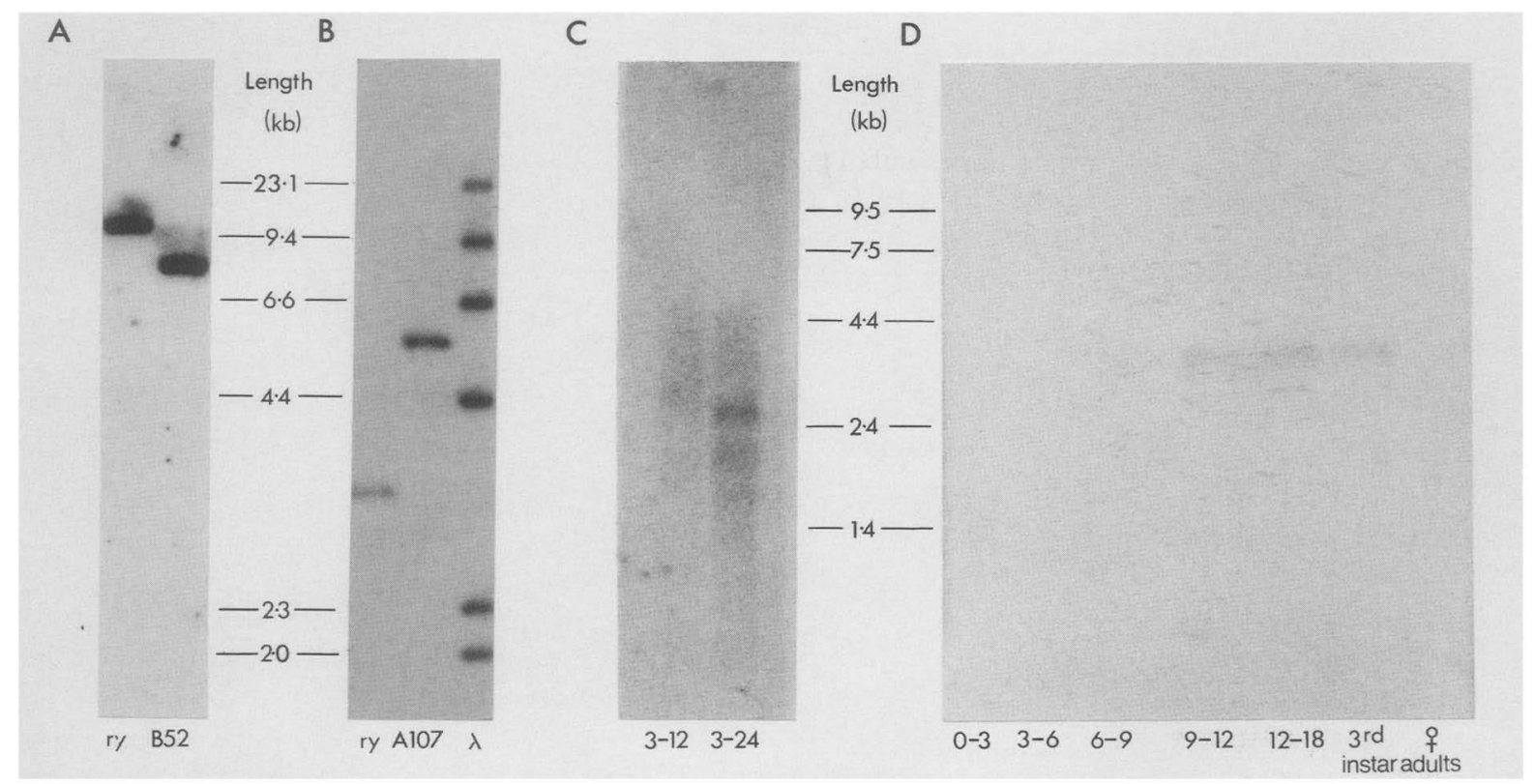

Figure 4. Southern and Northern analysis with rescued genomic probes from two different transposants, B52.1M3 and A109.1M3. Genomic DNA from transposant and $r y^{506}$ flies was digested with the enzyme used for genomic DNA rescue, electrophoresed, and transferred to nitrocellulose. For B52.1M3 $(A)$, the Southern blot was hybridized to a 1.5-kb NotI-HindIII-rescued genomic fragment. For A107.1 M3 (B), the probe was a 2.6-kb NotI-SalI fragment (for details of isolation, see Fig. IB). In both analyses, the hybridizing band in the transposant DNA is of the predicted size (the sum of the lengths of the probe and the Bluescript vector). This band differs from the band in DNA from ry ${ }^{506}$ flies that carry the original third chromosome containing no P[lArB] insertion. Markers were ${ }^{32}$ P-labeled fragments from a HindIII digest of $\lambda$ DNA. Northern analysis was performed with the B52.1M3 $(C)$ and A107.1M3 $(D)$ probes. Poly $(A)^{+}$RNA was isolated from embryos collected over the developmental times indicated (in hours) and, in the case of A107.1M3, from third-instar larvae and adult females. Each track contains $3 \mu \mathrm{g}$ of poly $(\mathrm{A})^{+} \mathrm{RNA}$. Blots were exposed to film for 2 weeks with a screen. Both probes hybridize to a single band, although the signals are faint, suggesting that the transcripts are rare and/or there is only a limited region of homology between the probes and the transcripts. Sizes were determined using unlabeled adenovirus RNA markers (BCL). Their migration positions are marked. The transcript is $\sim 2.6 \mathrm{~kb}$ in length for B52.1M3, whereas the hybridizing RNA is $-3.2 \mathrm{~kb}$ for A107.1M3.

during embryogenesis at a time consistent with the transposant staining pattern (see below). For A107.1M3, the same transcript is present in third-instar larvae, a developmental stage when the transposant also is stained in a specific pattern (G. Gilson, pers. comm.).

The distribution of transcripts from the 12 identified genes was examined by in situ hybridization to sections of wild-type embryos, ranging from 3 to $21 \mathrm{hr}$ in age. Clear signals could be detected above background with 5 of the 12 genomic probes tested. In three of these five cases, transcripts were expressed in a pattern different to the $\beta$-galactosidase pattern of the corresponding transposants. However, transcripts in the other two cases (B52.1M3 and A33.1M3) were distributed similarly to $\beta$ galactosidase. They will be discussed in the next section.

Signals above background were not detected with in situ hybridization to sections for 7 of the 12 genomic probes. In these cases, the assay may be insufficiently sensitive because only a small proportion of the genomic probe encodes sequences present in mature transcripts. Therefore, we screened a 12- to 24-hr embryonic library for cDNAs derived from RNAs encoded by some of these remaining genomic regions. cDNAs were isolated that hybridized to two of the probes (rescued from tranpo- sants A107.1M3 and A401.1M3); these cDNAs were subcloned in the EcoRI site of the Bluescript M13+KS plasmid vector. To confirm that they were derived from the appropriate genomic region, the clones were labeled with tritium and hybridized to salivary gland chromosomes. Both mapped to the correct chromosomal locus (data not shown). Then these probes were hybridized in situ to embryo sections. For both probes, a pattern of hybridization similar to the $\beta$-galactosidase staining pattern of the corresponding transposant was detected (see below). Therefore, in total, we have been able to analyze by in situ hybridization the expression pattern of seven genes that are located directly $3^{\prime}$ of a P[1ArB] insertion. As discussed in the following section, four of these genes appear to be controlled by the regulatory elements identified by the enhancer detector.

\section{Characterization of new developmentally regulated genes identified by enhancer detection}

Two of the four genes identified successfully in our screening procedure are expressed in a highly localized fashion in the embryo. Embryos of transposant B52.1M3 express $\beta$-galactosidase in many of the neurons of the peripheral nervous system (PNS), including sensory neu- 
rons in the head, and in some of the non-neuronal cells that contribute to the formation of sense organs /see Fig. $5 \mathrm{~A}$ and $\mathrm{B} \mid$. Staining is observed first in a small number of cells at the extended germ-band stage (stage 11; see Fig. $2 \mathrm{X}$ in Bellen et al. 1989). The transposon maps to subdivision 90D on the third chromosome. Flies homozygous for this insertion are viable and show no obvious morphological defects.

In situ hybridization to sections of wild-type embryos with the pB52.1M3H probe showed that the cross-hybridizing transcript is localized just below the epidermis in a segmentally repeated pattern that corresponds well to the $\beta$-galactosidase expression pattern of B52.1M3 (cf. Fig. 5B and D). Serial sections along the main axis of embryos showed that transcripts are not distributed uniformly under the epidermis. Strong hybridization signals at a particular position in one section may be absent in the corresponding position in the next section. This might be expected from the staining pattern of B52.1M3 (see Fig. 5A), because only isolated single cells or small groups of cells express $\beta$-galactosidase in each segment. In the head, there are much broader regions of hybridization, which also is consistent with the staining pattern. Thus, it appears that the hybridizing transcripts are localized in the same cells as $\beta$-galactosidase in transposant B52.1M3, suggesting that the regulatory sequences detected in this transposant do indeed control the expression of an adjacent gene.

Embryos from transposant A107.1M3 express $\beta$-galactosidase in cells that are located on the dorsal side of the ventral nerve cord and in part of the brain lobes (Fig. 5E). The cells are arranged in a ladder-like pattern, and we believe that they represent a subset of glial cells. A few individual cells at the periphery of the embryo, which may be part of the PNS, are stained also. P[lArB] is inserted at the boundary between subdivisions $94 \mathrm{~B}$ and C on the third chromosome. Flies homozygous for this chromosome show a weak roughened eye phenotype, which is poorly penetrant. Although a tritiated genomic probe failed to give a signal above background on hybridization to wild-type embryo sections, a probe made from the corresponding cDNA hybridized to a region just dorsal to the ventral nerve cord (Fig. 5F and G). In more lateral sections it was also possible to observe hybridization in part of the brain lobes. Again this pattern is entirely consistent with the $\beta$-galactosidase staining pattern of the transposant strain.

Transcripts with the expected embryonic distribution were detected also with a cDNA probe that is homologous to a genomic clone from transposant A401.1M3. This strain expresses $\beta$-galactosidase throughout the CNS and more strongly in the proventriculus (data not shown). The P[1ArB] insertion maps to $92 \mathrm{~A}$ on the third chromosome and leads to a homozygous lethal phenotype. In situ hybridization shows that the gene encoded by the region adjacent to $\mathrm{P}[\mathrm{lArB}]$ also is expressed throughout the CNS. However, we have been unable to observe hybridization signals in the proventriculus thus far.

Finally, for the transposant A33.1M3, a correlation be- tween staining pattern and transcript distribution is found both in embryos and adult ovaries. This strain, in which the insertion has led to a recessive female sterile mutation (Grossniklaus et al. 1989), will be described elsewhere.

\section{Discussion}

In Bellen et al. (1989), a method has been described for rapidly generating many strains containing the enhancer detector transposon $\mathrm{P}[\mathrm{lArB}]$, and the staining patterns of these strains have been analyzed. Now we have presented a molecular study of a number of the resulting transposants. Our results demonstrate clearly that the enhancer detector system may be used to efficiently screen for genes on the basis of their embryonic transcript distribution and to subsequently clone those that are expressed in an interesting pattern. Because so many transposants stain subsets of cells in the head and nervous system (see Bellen et al. 1989), the technique should be particularly useful in the study of these regions. A vast number of regulatory elements with different specificities also can be detected at other stages of development (Fasano and Kerridge 1988; Grossniklaus et al. 1989; Gibson and Gehring 1990), and recent evidence suggests that genes expressed at these later stages (e.g., during oogenesis) may be cloned by this technique also (U. Grossniklaus, unpubl.). P-element-mediated enhancer detection is therefore likely to prove important in future investigations of many processes in Drosophila development, especially as it can identify genes that are not analyzed easily by classical genetic techniques.

\section{A large proportion of transposants reveal the expression pattern of a neighboring gene}

By mapping the enhancer detector transposon position of 68 insertion strains cytologically, 6 strains have been identified in which the staining pattern seems to reflect the expression pattern of a gene adjacent to the insertion (Bellen et al. 1989). We confirmed this at the molecular level in two cases. In addition, we analyzed 26 different transposants by a relatively crude screening procedure. In four of the seven examples where a rescued genomic fragment was shown to encode a transcript that could be detected by in situ hybridization to embryo sections, the transcript was expressed in the pattern predicted from the corresponding transposant. In those cases where a transcript was not observed by Northern analysis or by in situ hybridization with the genomic probe, it is still possible that a nearby gene may be controlled by the regulatory elements that have been identified. For example, in some instances, the genomic probe may share only a short stretch of homology with the transcript that it encodes, or the transcript may be expressed at levels below the limit of detection for Northern analysis or in situ hybridization (e.g., see Fig. 4). Furthermore, both in the cases where no transcript is detected and where a transcript is expressed in different tissues from those expected, there may still be genes nearby that are controlled by the detected regulatory element. In this re- 
Wilson et al.
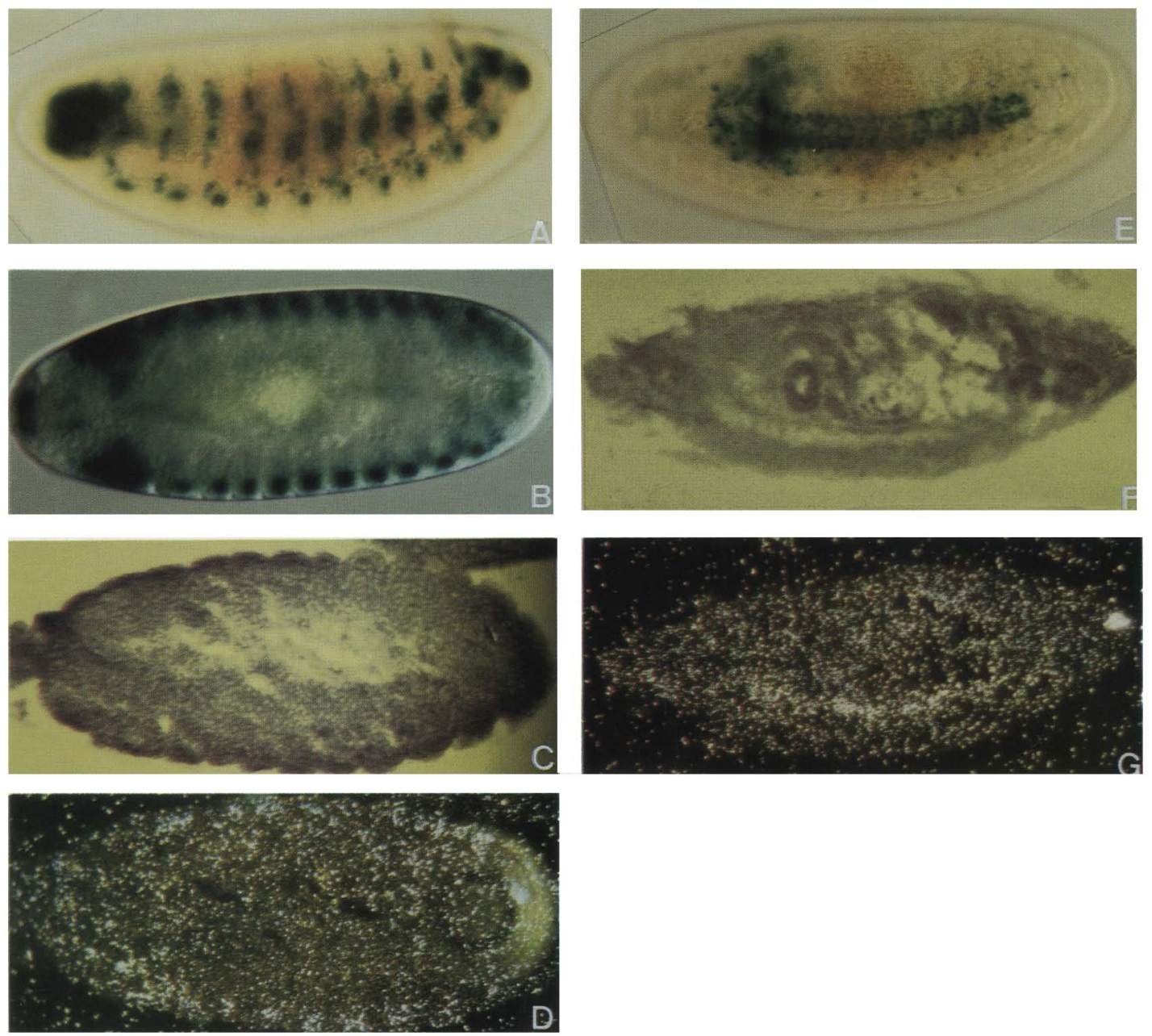

Figure 5. The $\mathrm{P}[\mathrm{ArB}]$ insertions in transposants $\mathrm{B} 52.1 \mathrm{M} 3$ and $\mathrm{A} 107.1 \mathrm{M} 3$ lie adjacent to appropriately regulated tissue-specific genes. Lateral $(A)$ and dorsal $(B)$ (focal plane at about the middle of the embryo) view of whole-mount 13-to 16-hr-old (stage 16) embryos from transposant strain B52.1M3 stained for $\beta$-galactosidase activity. Staining is observed in a relatively broad region in the head and in patches under the cuticle in each segment $(B)$. Most of the neurons of the PNS and some non-neuronal sensory cells express $\beta$-galactosidase. Below are bright-field $(C)$ and dark-field $(D)$ photographs of a frontal section of a wild-type embryo probed with the tritiated 5-kb NotI-HindIII-rescued genomic fragment from transposant B52.1M3. The transcript distribution observed closely matches the staining pattern in $B$. In particular, note the subcuticular location of silver grains in each segment. $(E)$ Ventrolateral view of a $16-$ to 20-hr-old (stage 17) whole-mount embryo from transposant strain A107.1M3 stained for $\beta$-galactosidase activity. Staining is observed in the brain lobes and in cells arranged in a ladder-like fashion at the dorsal surface of the ventral nerve cord. The latter are probably glial cells. Below are bright-field $|F\rangle$ and dark-field $|G|$ photographs of a parasagittal section of an embryo at approximately the same stage of development as in $E$. The probe is a tritiated cDNA fragment of $\sim 1.5 \mathrm{~kb}$ in length, which is encoded partly by the genomic region lying directly $3^{\prime}$ of the $\mathrm{P}[\mathrm{lArB}]$ insertion in transposant $\mathrm{A} 107.1 \mathrm{M} 3$. Hybridizing transcripts are localized at the dorsal surface of the ventral nerve cord $(F)$ and can be observed in part of the brain lobes in other sections (data not shown). This pattern closely resembles the staining pattern in $E$.

gard, it should be noted that generally only relatively short genomic regions lying $3^{\prime}$ of the insertion have been examined (see Materials and methods); in several cases, the regulated gene might lie entirely $5^{\prime}$ of $\mathrm{P}[\mathrm{lArB}$ ] (as in Fig 1C) or farther $3^{\prime}$ of the cloned region.

Further evidence for the efficiency of the enhancer detector technique may be drawn from our results with the transposants that stain in a spatially restricted pattern at cellular blastoderm (Bellen et al. 1989). Because early pattern formation previously has been studied geneti- cally in much more detail than any other developmental process in embryogenesis, a far greater proportion of the zygotic genes involved are known. Their expression frequently is regulated spatially at cellular blastoderm. Two of the three transposants that show spatially restricted patterns of staining at this stage map to known genes (sloppy-paired and spalt; Bellen et al. 1989). At least in the case of spalt, which lies entirely $5^{\prime}$ of the $\mathrm{P}[\mathrm{lArB}]$ insertion (J. Bernholz, pers. comm.), the gene would not have been recognized by the simple cloning 
and screening procedure with $3^{\prime}$ genomic sequences used here. In light of all of these arguments, we believe that a large proportion of transposants with a temporally or spatially regulated pattern of $\beta$-galactosidase expression could be used successfully to isolate a similarly controlled gene.

Some of the transposants that have been analyzed at the molecular level are stained in complex patterns that mark many different tissues and cells. Such patterns might reflect the presence of multiple regulatory elements near the $P[1 \mathrm{ArB}]$ insertion, each one of which controls a different gene. Indeed, in one example (A401.1M3), only part of the $\beta$-galactosidase pattern may be reproduced in the distribution of a neighboring gene's transcript. However, more detailed studies would need to be performed to confirm that the transcript is truly absent in the small region (part of the proventriculus) where gene expression presently has not been observed. In contrast, there are other cases of complex staining patterns that match extremely well with the expression pattern of a single neighboring gene or represent part of the expression pattern of a single gene (collagen type IV, fasciclin III, and Toll; Bellen et al. 1989). Therefore, in many transposants the regulatory elements identified appear to act in concert to control a single gene or a set of genes.

\section{P-element-mediated enhancer detector screens are particularly efficient in identifying the rejulatory elements of genes}

About $65 \%$ of $\mathrm{P}[\mathrm{lArB}]$ transposants stain for $\beta$-galactosidase activity in a spatially restricted pattern (Bellen et al. 1989|. One possible interpretation of these results is that there are many enhancer-like elements scattered throughout the genome that do not regulate genes directly but, instead, represent binding sites for regulatory proteins or just randomly recurring consensus sequences. However, our results would suggest that many of these regulatory elements do control neighboring genes and that there may be relatively few areas in the Drosophila genome where P[1ArB] can insert without being placed under the control of the regulatory elements of a gene. This is at least consistent with the hypothesis that the genome may be divided into domains that act as autonomous regulatory regions imposing specific restrictions on gene activity (see Gasser and Laemmli 1986).

The frequency with which gene regulatory elements are detected may be biased by the insertion site specificity that has been reported for P elements. Not only are they generally located outside heterochromatin, but they are found often in the $5^{\prime}$ upstream and untranslated regions of genes that they have mutated (for review, see Engels 1988). Indeed, in the two examples that we have characterized in detail, $\mathrm{P}[\mathrm{lArB}]$ is located near the transcription start sites of both genes.

Even if $\mathrm{P}$ elements insert relatively randomly in the genome, our results may be less surprising than they appear initially. Unlike many other higher eukaryotes, $D$. melanogaster has a relatively compact genome with a haploid length of $1.65 \times 10^{5} \mathrm{~kb}$ (Rudkin 1972). Estimates based on mutational analyses suggested that there are $\sim 5000$ essential genes in the genome, about 1 every $30 \mathrm{~kb}$ (Rudkin 1965). However, other studies indicate that the total number of genes /essential and nonessential) may be as much as threefold higher. Spierer et al. (1983) and others suggested that the average length of a Drosophila polytene chromosomal band is $\sim 30 \mathrm{~kb}$. Two studies indicate that two to three transcription units are usually present in each band (Bossy et al. 1984; Voelker et al. 1985). Therefore, on average, a gene may be found in every $10-15 \mathrm{~kb}$ of genomic sequence. Because enhancers are known to act over distances of $50 \mathrm{~kb}$ or more in Drosophila (Peifer et al. 1987), it may be difficult to recover $\mathrm{P}[\mathrm{lArB}]$ insertions that are not affected by the regulatory elements of a gene.

The frequency at which $\mathrm{P}[\mathrm{lArB}]$ detects regulatory sequences of genes and the great variety of staining patterns observed suggest that the enhancer detector can respond to many different gene regulatory elements. Nevertheless, there are some limitations to the technique. Not all of the regulatory elements of a gene may be detected by a single P $[1 \mathrm{ArB}]$ insertion, particularly if the gene has a complex genomic organization. For example, the insertion that appears to lie near or within the Toll gene (see Bellen et al. 1989) fails to reveal the maternal component of Toll expression and some of the spatially restricted zygotic expression. One of several possible explanations for this result is that the distance of $\mathrm{P}[\mathrm{lArB}]$ from a given regulatory element and its orientation may affect its ability to detect that element. Furthermore, the expression pattern of genes regulated by elements that can act only at a short distance from the TATA box may be difficult or impossible to detect. However, because P elements may often insert in genes near the start of transcription, it is conceivable that even these proximal regulatory elements may be detected in some cases.

Applications of enhancer detector screens for isolating developmental genes

Our results indicate that P-element-mediated enhancer detector screens are an efficient method for identifying genes on the basis of their expression pattern. The technique will allow the classification and subsequent molecular analysis of previously uncloned genes, including those that could not be studied easily purely by a classical genetic analysis. When Nüsslein-Volhard, Wieschaus, and Jürgens screened embryonic lethal mutations for those that affect cuticular phenotype in first-instar larvae, they found that nearly $90 \%$ of these mutations have no visible defect (e.g., see Wieschaus et al. 1984). Although Eberl and Hilliker (1988) suggested recently that a greater proportion of mutations can lead to some kind of visible phenotype in embryos or first-instar larvae, the effects of the majority of recessive lethal mutants still cannot be classified by simple morphological studies. The use of enhancer detector vectors in a P-ele- 
ment mutagenesis experiment should allow the classification of such mutants on the basis of gene expression pattern. However, in light of our results for the Toll and sloppy-paired insertions (Bellen et al. 1989), it may be more efficient to study all transposants that stain in the tissue or pattern of interest, rather than restrict a screen to transposants that have a mutant phenotype. Indeed, nonlethal insertions in or near an essential gene may indicate a role for that gene (on the basis of expression pattern) at stages after the lethal phase of a loss-of-function mutant (e.g., see Grossniklaus et al. 1989). In such cases, the gene's function may be analyzed genetically by inducing lethal mutations (see below) and studying the phenotype of mitotically recombined homozygous clones in the tissue of interest.

As we have discussed already, perhaps as many as two-thirds of all genes are not essential for viability in Drosophila. Presumably, many of these nonessential genes are likely to play some developmental role. However, because of redundancy, the function of a gene in this class may be largely substituted by other related genes, so that mutations in the gene have no obvious phenotypic effects. Such a phenomenon has been observed for the two ras genes of yeast, where both genes must be disrupted to prevent growth (Kataoka et al. 1984; Tatchell et al. 1984). Our results with the fasciclin III gene (confirmed by deletion studies; T. Elkins, Y. Hiromi, P. Snow, and C. Goodman, pers. comm.) suggest that the protein that it encodes, which is thought to be involved in cell-cell communication (Patel et al. 1987), also falls into this class of nonessential gene products. Therefore, members of any group of nonessential genes, which are inaccessible to classical genetic analysis, may now be isolated and studied by enhancer detection.

Once a new gene is recognized in an enhancer detector screen, not only can it be cloned, but it can easily be analyzed genetically. Imprecise excisions of the P[lArB $]$ insertion in flies carrying a stable source of transposase (e.g., Cooley et al. 1988; Robertson et al. 1988) may create a deletion of the surrounding region, as we found for the insertion near Toll (Bellen et al. 1989). Alternatively, classical mutagenesis experiments may be performed in which flies are screened for loss of one of the two marker genes, $A d h^{+}$and $r y^{+}$. Because it is possible to select positively for loss of $A d h^{+}$activity using the chemical pentyne-3-ol (O'Donnell et al. 1975), several hundred thousand chromosomes may be analyzed in a single mutagenesis experiment. Mutations generated by either deletion technique should be particularly useful for assessing the function of a gene with a complex expression pattern. Indeed, because the expression pattern of the deleted gene will be known already, it will be possible to focus attention on regions that are most likely to be affected and therefore recognize even very subtle phenotypic changes. Thus, the considerable advantages of the enhancer detector technique can be coupled to the more standard genetic approaches that have made Drosophila such an important model system in the study of development.

Enhancer detection is a powerful technique for studying development in Drosophila and might be equally suited to other higher organisms that are not so easily amenable to systematic genetic analysis. Two groups have reported recently the generation of transgenic mice that carry enhancer detector vectors (Allen et al. 1988; Grossler et al. 1989|. In the stable lines that they constructed, they also observed a number of complex, but spatially restricted patterns of $\beta$-galactosidase expression, although most of their lines did not express the reporter gene. In light of our results, it seems possible that enhancer detection will also be an important method for isolating developmentally regulated genes in the mouse.

\section{Materials and methods}

Flies carrying either $\mathrm{P}[1 \mathrm{ArB}]$ or $\mathrm{P}[\operatorname{lwB}]$ (see below) and further details concerning some of the techniques described are available on request (see also Wilson et al. 1990).

\section{Construction of P-element enhancer detector vectors}

Cloning was performed by standard procedures (see Maniatis et al. 1982). In a preliminary series of steps, the $0.8-\mathrm{kb}$ HindIII fragment of pUChsneo (Steller and Pirrotta 1986), which contains the two P-element 31 -bp repeats, was modified at its boundaries. It was first end-filled using the Klenow fragment of $E$. coli DNA polymerase and ligated to pEMBL18 (Dente et al. 1983), which had been digested with XbaI and SalI, treated with calf intestinal alkaline phosphatase (CIAP) and end-filled with Klenow enzyme. A clone was selected (p6) in which the HindIII site nearer the 5' P-element repeat had been regenerated by fusion to the end-filled Sall overhang; at the other end of the insert, the XbaI site, but not the HindIII site, was regenerated.

The $X b a I$ site of p6 was removed by digestion with $X b a \mathrm{I}$, end-filling with Klenow enzyme, and religation. The resulting clone, p7, was digested with KpnI and BamHI; the plasmid then was isolated from a gel, and the small polylinker fragment from a KpnI-BamHI digest of pW8 (Klemenz et al. 1987) was inserted to give plasmid p8. In $\mathrm{p} 8$, the HindIII fragment from pUChsneo was delimited by a HindIII site only near the 5 ' P repeat. The insert could be removed by digesting with both KpnI and HindIII; it contains a NotI site close to the KpnI site.

To assemble the series of insertion vectors, clone pW6 (Klemenz et al. 1987) first was digested with SphI and StuI, and the SphI-generated 3' overhang was removed by incubation with T4 DNA polymerase. The $4.5-\mathrm{kb}$ product containing the heat shock-mini-white ${ }^{+}$gene fusion was ligated into the Bluescript M13-KS vector (Stratagene) that had been digested with NotI, treated with CIAP, and end-filled with Klenow enzyme. A clone $(\mathrm{pl} 0)$ was selected that contained the $5^{\prime}$ end of the white ${ }^{+}$ fusion gene nearer the $X b a I$ site of the Bluescript polylinker. The HindIII-KpnI fragment of $\mathrm{p} 8$ containing the P-element repeats was subcloned into the HindIII and KpnI sites of plO to give clone p13. Subsequently, the $4.3-\mathrm{kb}$ HindIII fragment of pLacA92 (O'Kane and Gehring 1987) was inserted into the HindIII site of p13 to form a clone, P-lwB, in which the two parts of the $5^{\prime}$ P-element terminus had been reunited, giving a functional transposon $\mathrm{P}\left[\underline{I} a c Z ; \underline{w}^{+}\right.$; Bluescript $\mid$. In a further modification, the $3.2-\mathrm{kb} X b a \mathrm{I}$ fragment (Posakony et al. 1986) from the $A d h^{+}$-containing plasmid sAF2 (Goldberg 1980) was inserted into the $\mathrm{XbaI}$ site of P-lwB. The inserted fragment in the selected construct, P-IAwB [carrying the transposon $\mathrm{P}($ IacZ; $\underline{A} d h^{+} ; \underline{w}^{+}$; Bluescript)], is oriented so that the $A d h^{+}$promoter is adjacent to the mini-white fusion gene. 
To substitute the white ${ }^{+}$gene with the $r y^{+}$gene, the $7.2-\mathrm{kb}$ HindIII fragment of Carnegie 20 (Rubin and Spradling 1983), containing the $\mathrm{ry}^{+}$gene, was subcloned into the HindIII site of Bluescript $\mathrm{Ml3}^{+} \mathrm{KS}$, so that the $5^{\prime}$ end of the gene was nearer the $X b a$ I site of the Bluescript polylinker. This clone (p41) was digested with NotI and XbaI, and the NotI-XbaI fragment of $P$-lwB that contains the P-lacZ fusion gene was inserted. The resulting plasmid, $\mathrm{P}-\mathrm{lrB}$ [carrying the transposon $\mathrm{P}\left(I_{-} a c Z ; r y^{+}\right.$; Bluescript $\mid$, was linearized with $X b a I$, and the $3.2-\mathrm{kb} X b a I$ fragment from the $A d h^{+}$gene (Posakony et al. 1986) was added so that the $5^{\prime}$ end of the $A d h^{+}$gene was nearer the $r y^{+}$gene. This final construct, P-lArB [containing the transposon $\mathrm{P}(\mathrm{lac} Z$; $\underline{A} d h^{+} ; r y^{+}$; Bluescript $\left.\mid\right]$, is shown in Figure 1A. Further details of the cloning procedure and maps of the constructs are available on request.

Procedures for obtaining transformants and transposants carrying $\mathrm{P}[\mathrm{A} \mathrm{ArB}]$ are described in Bellen et al. (1989). We generated fly strains carrying the transposons from all of the new vectors except P-1AwB. As we performed only a limited number of injections with the latter, it is still not clear whether this plasmid is defective in some way.

Subsequent analysis of a number of transposants has shown that the $A d h$ gene in $\mathrm{P}] \mathrm{lArB}$ ] is expressed, on average, at $\sim 50 \%$ of the level found in normal adults (data not shown). This result is in agreement with data on other constructs carrying the $A d h^{+}$gene (Posakony et al. 1986).

\section{Preparation of genomic DNA and poly $(A)^{+}$RNA}

Genomic DNA was isolated from various transposants using a protocol modified from Bingham et al. (1981). Typically 100-200 flies were homogenized in $3 \mathrm{ml}$ of ice-cold homogenization buffer [10 mM Tris- $\mathrm{HCl}(\mathrm{pH} 8.0), 60 \mathrm{~mm} \mathrm{NaCl}, 10 \mathrm{~mm}$ EDTA, $0.15 \mathrm{~mm}$ spermidine, $0.5 \%$ (vol/vol) Triton X-100). After removing debris by filtration through fine gauze, nuclei were pelleted twice in $5-\mathrm{ml}$ Nunc tubes by centrifugation at $7000 \mathrm{rpm}$ for $7 \mathrm{~min}$ in a Sorvall SS-34 rotor cooled to $4^{\circ} \mathrm{C}$. The final pellet was resuspended in $1.8 \mathrm{ml}$ of homogenization buffer; $0.2 \mathrm{ml}$ of $20 \%$ Sarkosyl was added, and the solution was mixed by gentle inversion. Twenty microliters of $10 \mathrm{mg} / \mathrm{ml}$ proteinase $\mathrm{K}$ was added, and the sample was incubated at $50^{\circ} \mathrm{C}$ for $2-3 \mathrm{hr}$. Then the nuclear lysate was extracted once with phenol and once with chloroform before being precipitated with ethanol. The precipitate was pelleted, and the pellet was washed with $80 \%$ ethanol and, finally, redissolved in TE ( $1 \mu 1 /$ fly homogenized). This procedure usually yields $\sim 0.1-0.2 \mu \mathrm{g}$ DNA/fly.

Total RNA was extracted from staged embryos, larvae, and adult flies by the guanidium/cesium chloride method (see Maniatis et al. 1982) or by the precipitation method of Chirgwin et al. (1979). Poly(A) ${ }^{+}$RNA was isolated subsequently as described by Aviv and Leder (1972).

\section{Cloning of genomic DNA}

For plasmid rescue (see Fig. 1B) the protocol of Pirrotta (1986) was followed. A phenol/chloroform extraction and ethanol precipitation was included between the digestion and ligation procedures because, at least in the case of HindIII, heat treatment does not completely inactivate the restriction enzyme. We ligated approximately two fly equivalents of DNA in a $200 \mu \mathrm{l}$ volume of $50 \mathrm{~mm}$ Tris- $\mathrm{HCl}, 10 \mathrm{~mm} \mathrm{MgCl}_{2}$, and $1 \mathrm{mM} \mathrm{rATP}$, containing 1 unit of T4 DNA ligase. After precipitation and redissolving in a smaller volume, the ligation mixture was used to transform XL1-Blue cells (Stratagene) made competent essentially by following protocol 3 of Hanahan (1985), except that the cells were resuspended finally in RF2 buffer to $1 / 60$ the orig- inal culture volume. We recovered between 0 and 30 colonies per fly equivalent of genomic DNA by this method.

Clones were only analyzed further if more than one colony harboring the same rescued plasmid was obtained after transformation. To rescue genomic clones from the 28 selected transposants, first we used the restriction enzymes HindIII and SalI for plasmid rescue experiments. Clones that contained genomic fragments between 2.5 and $7 \mathrm{~kb}$ were selected to perform further analyses. If such clones could not be generated from a particular transposant, $\mathrm{XBaI}$ and $\mathrm{ClaI}$ also were used to obtain a suitable clone. However, in eight cases, the rescued genomic fragment was, by necessity $>7 \mathrm{~kb}$ in length. We were unable to recover a genomic clone for two other transposants.

\section{Southern, Northern and dot blot analysis and cDNA library screens}

Fragments isolated from rescued genomic clones were nicktranslated according to Rigby et al. (1977).

For genomic Southern analysis, DNA from each transposant line was digested with the enzyme used for plasmid rescue of the corresponding genomic clone. One hybridizing band in this digest should be of equal length to the corresponding linearized rescued clone. Furthermore, genomic DNAs from flies carrying the original chromosome into which $\mathrm{P}[\mathrm{IArB}]$ inserted and from flies carrying any other homologous chromosome in the transposant strain also were analyzed in the same way. Digests of these preparations generally would be expected to contain hybridizing fragments of different lengths to the insertion-associated fragment in digested transposant DNA. Approximately $1-3 \mu \mathrm{g}$ of digested genomic DNA was fractionated by agarose gel electrophoresis for genomic Southern analysis. Blots were prepared as described by Southern (1975) and were prehybridized, hybridized, and washed at high stringency, according to McGinnis et al. (1984).

For Northern analysis, $3 \mu \mathrm{g}$ of poly $(\mathrm{A}){ }^{+}$RNA isolated from embryos of different stages, third-instar larvae, or adult females was fractionated by electrophoresis on a $1.1 \%$ agarose-formaldehyde gel (Rozek and Davidson 1983). RNA was transferred to nitrocellulose, as described by Southern (1975). Blots were prehybridized and hybridized at $42^{\circ} \mathrm{C}$ in $50 \%$ formamide at high stringency, as described by McGinnis et al. (1984). All Northern blots were washed in $0.2 \times \mathrm{SSC}, 0.1 \%$ SDS at $60^{\circ} \mathrm{C}$ for $2 \times 15$ min. Blots were later hybridized to a probe made from a cDNA clone of Drosophila elongation factor $1 \alpha$ (cDM 49; Hovemann et al. 1988) to confirm equal loading and integrity of RNA from different time points.

To obtain cDNAs, a $\lambda$ gt 10 cDNA library, containing cDNAs made from mRNA extracted from embryos between 12 and 24 hr of embryonic development (a gift from Larry Kauvar), was used. For each probe, $\sim 2 \times 10^{5}$ to $3 \times 10^{5}$ clones were screened. Positive clones were isolated by standard procedures (Maniatis et al. 1982).

\section{Sequencing}

Single-stranded Bluescript templates were generated, as described in the Bluescript instruction manual (Stratagene). Sequencing was performed by the method of Sanger et al. (1977), using an oligonucleotide complementary to part of the 3' P-element sequence.

\section{Staining for $\beta$-galactosidase activity}

Embryos were stained as described by Bellen et al. (1989). 
Immunocytochemical staining for fasciclin III protein

The monoclonal antibody against fasciclin III protein $/ \mathrm{mAb}$ 2D5) was a gift from N. Patel and C. Goodman (see Patel et al. 1987). Immunocytochemistry was performed essentially as described by Steller et al. (1987). Embryos were incubated in a 2:1 mixture of buffer solution and supernatant containing a monoclonal antibody against the fasciclin III protein (Patel et al. 1987). They were washed and subsequently incubated with a $1: 300$ dilution of rabbit anti-mouse antibody coupled to horseradish peroxidase (HRP), after which they were incubated in a $1: 200$ dilution of swine anti-rabbit antibody coupled to HRP. Embryos were stained for HRP activity after washing, as described by Patel et al. (1987).

In situ hybridization to polytene chromosomes and embryonic tissue sections

Tritiated probes were synthesized as described by Baumgartner (1988) in a procedure modified from Hafen et al. (1983). The two major modifications were shorter single-stranded DNA probes (20-50 bases) and higher specific activity of these probes $\left(5 \times 10^{7}\right.$ to $2 \times 10^{8} \mathrm{dpm} / \mu \mathrm{g}$ of DNA $)$. In situ hybridization of these probes to larval polytene chromosomes followed the procedure described by Langer-Safer et al. (1982). Washing conditions were those used by Hafen et al. (1983) for tissue sections. In situ hybridization to embryonic tissue sections was carried out as described by Hafen et al. (1983).

\section{Acknowledgments}

We thank Peter Snow for the fasciclin III clones, Nipam Patel and Corey Goodman for the fasciclin III antibody, Yannick Le Parco for the collagen clones, and Larry Kauvar for the cDNA library. We are grateful also to Peter Snow, Tom Elkins, Yash Hiromi, Corey Goodman, Bruce Blumberg, Albert MacKrell John Fessler, Juliane Bernholtz, and Greg Gibson for information supplied prior to publication. We would like to thank Tony Percival-Smith, Leslie Pick, Markus Affolter, Kay Lang, and Walter Keller for helpful comments on the manuscript and Erika Wenger-Marquardt for its efficient preparation. This work was supported by a Royal Society exchange fellowship to C.W., an American Cancer Society fellowship to R.K.P., a NATO fellowship to H.B., fellowships from EMBO and the Roche Foundation to C.O.K., the Swiss National Science Foundation, and the Kantons of Basel Stadt and Basel-Landschaft.

\section{References}

Allen, N.D., D.G. Cran, S.C. Barton, S. Hettle, W. Reik, and M.A. Surani. 1988. Transgenes as probes for active chromosomal domains in mouse development. Nature 333: 852855.

Aviv, H. and P. Leder. 1972. Purification of biologically active globin messenger RNA by chromatography on oligothymidylic-acid cellulose. Proc. Natl. Acad. Sci. 69: 1408-1412.

Baumgartner, S. 1988. 'Patterns of paired and gooseberry transcripts in wild-type and segmentation mutant embryos imply a combinatorial regulation of segmentation genes in Drosophila.' Ph.D. thesis, University of Basel.

Bellen, H.J., C.J. O'Kane, C. Wilson, U. Grossniklaus, R.K. Pearson, and W.J. Gehring. 1989. P-element-mediated enhancer detection: A versatile method to study development in Drosophila. Genes Dev. 3: $1288-1300$.

Bingham, P.M., R. Levis, and G.M. Rubin. 1981. Cloning of DNA sequences from the white locus of $D$. melanogaster by a novel and general method. Cell 25: 693-704.
Blumberg, B., A.J. MacKrell, P.F. Olson, M. Kurkinen, M.J. Monson, J.E. Natzle, and J.H. Fessler. 1987. Basement membrane procollagen IV and its specialized carboxyl domain are conserved in Drosophila, mouse and human. J. Biol. Chem. 262: 5947-5950.

Blumberg, B., A.J. MacKrell, and J.H. Fessler. 1989. Drosophila basement membrane procollagen $\alpha 1(I V)$ : Complete cDNA sequence, genomic structure and general implications for supramolecular assemblies. I. Biol. Chem. 263: 1832818337.

Bossy, B., L.M.C. Hall, and P. Spierer. 1984. Genetic activity along $315 \mathrm{~kb}$ of the Drosophila chromosome. EMBO $/$. 3: $2537-2541$.

Campos-Ortega, J.A. and V. Hartenstein. 1985. The embryonic development of Drosophila melanogaster. Springer-Verlag, Berlin.

Cecchini, J.-P., B. Knibiehler, C. Mirre, and Y. Le Parco. 1987. Evidence for a type IV related collagen in Drosophila melanogaster. Eur. I. Biochem. 165: 587-593.

Chirgwin, J.M., A.E. Przybyla, R.J. McDonald, and W.J. Rutter. 1979. Isolation of biologically active ribonucleic acid from sources enriched in ribonuclease. Biochemistry 18: 52945299.

Cooley, L., R. Kelley, and A. Spradling. 1988. Insertional mutagenesis of the Drosophila genome with single P-elements. Science 239: 1121-1128.

Dente, L., G. Cesareni, and R. Cortese. 1983. pEMBL: A new family of single stranded plasmids. Nucleic Acids Res. 11: $1645-1655$.

Eberl, D.F. and A.J. Hilliker. 1988. Characterization of X-linked recessive lethal mutations affecting embryonic morphogenesis in Drosophila melanogaster. Genetics 118: 109-120.

Engels, W.R. 1988. P elements in Drosophila. In Mobile DNA (ed. D.E. Berg and M.M. Howe), pp. 437-484. American Society for Microbiology, Washington, D.C.

Fasano, L. and S. Kerridge. 1988. Monitoring positional information during oogenesis in adult Drosophila. Development 104: 245-253.

Fujita, S.C., S.L. Zipursky, S. Benzer, A. Ferrus, and S.L. Shotwell. 1982. Monoclonal antibodies against the Drosophila nervous system. Proc. Natl. Acad. Sci. 79: 7929-7933.

Gans, M., C. Audit, and M. Masson. 1975. Isolation and characterization of sex-linked female sterile mutants in Drosophila melanogaster. Genetics 81: 683-704.

Gasser, S.M. and U.K. Laemmli. 1986. Cohabitation of scaffold binding regions with upstream/enhancer elements of three developmentally regulated genes of D. melanogaster. Cell 46: $521-530$.

Gibson, G. and W. Gehring. 1990. P-element-mediated enhancer detection in imaginal discs and third instar larval brain of Drosophila melanogaster. Dros. Info. Serv. 69. (in press).

Goldberg, D.A. 1980. Isolation and partial characterization of the Drosophila alcohol dehydrogenase gene. Proc. Natl. Acad. Sci. 77: 5794-5798.

Gossler A, A.L. Joyner, J. Rossant, and W.C. Skames. 1989. Mouse embryonic stem cells and reporter constructs to detect developmentally regulated genes. Science 244: 463465.

Grossniklaus, U., H.J. Bellen, C. Wilson, and W.J. Gehring. 1989. P-element-mediated enhancer detection applied to the study of oogenesis in Drosophila. Development (in press).

Hafen, E., M. Levine, R.L. Garber, and W.J. Gehring. 1983. An improved in situ hybridization method for the detection of cellular RNAs in Drosophila tissue sections and its application for localizing transcripts of the homeotic Antennapedia gene complex. EMBO I. 2: 617-623. 
Hanahan, D. 1985. Techniques for transformation of E. coli. In DNA cloning, a practical approach. (ed. D.M. Glover), vol. 1, pp. 109-135. IRL Press, Oxford.

Hovemann, B., S. Richter, U. Walldorf, and C. Cziepluch. 1988. Two genes encode related cytoplasmic elongation factors $1 \alpha$ (EF- $1 \alpha$ ) in Drosophila melanogaster with continuous and stage specific expression. Nucleic Acids Res. 16:31753194.

Kataoka, T., S. Powers, C. McGill, O. Fasano, J. Strathern, J. Broach, and M. Wigler. 1984. Genetic analysis of yeast RAS1 and RAS2 genes. Cell 37: 437-445.

Klemenz, R., U. Weber, and W.J. Gehring. 1987. The white gene as a marker in a new P-element vector for gene transfer in Drosophila. Nucleic Acids Res. 15: 3947-3959.

Langer-Safer, P.R., M. Levine, and D.C. Ward. 1982. Immunological method for mapping genes on Drosophila polytene chromosomes. Proc. Natl. Acad. Sci. 79: 4381-4385.

Le Parco, Y., J.-P. Cecchini, B. Knibiehler, and C. Mirre. 1986. Characterization and expression of collagen-like genes in Drosophila melanogaster. Biol. Cell 56: 217-226.

Maniatis, T., E.F. Fritsch, and J. Sambrook. 1982. Molecular cloning: A laboratory manual. Cold Spring Harbor Laboratory, Cold Spring Harbor, New York.

McGinnis, W., M.S. Levine, E. Hafen, A. Kuriowa, and W.J. Gehring. 1984. A conserved DNA sequence in homeotic genes of the Drosophila Antennapedia and bithorax complexes. Nature 308: 428-433.

Mirre, C., J.-P. Cecchini, Y. Le Parco, and B. Knibiehler. 1988. De novo expression of a type IV collagen in Drosophila embryos is restricted to mesodermal derivatives and occurs at germ band shortening. Development 102: 369-376.

Natzle, J.E., J.M. Monson, and B.J. McCarthy. 1982. Cytogenic location and expression of collagen-like genes in Drosophila. Nature 296: 368-371.

Nüsslein-Volhard, C. and E. Wieschaus. 1980. Mutations affecting segment number and polarity in Drosophila. Nature 287: 795-801.

O'Donnell, J., L. Gerace, F. Leister, and W. Sofer. 1975. Chemical selection of mutants that affect alcohol dehydrogenase in Drosophila. II. Use of 1-pentyne-3-ol. Genetics 79: 7383.

O'Kane, C.J. and W.J. Gehring. 1987. Detection in situ of genomic regulatory elements in Drosophila. Proc. Natl. Acad. Sci. 84: 9123-9127.

Patel, N.H., P.M. Snow, and C.S. Goodman. 1987. Characterization and cloning of fasciclin III: A glycoprotein expressed on a subset of neurons and axon pathways in Drosophila. Cell 48: 975-988.

Peifer, M., F. Karch, and W. Bender. 1987. The bithorax complex: Control of segmental identity. Genes Dev. 1: 891-898.

Perucho, M., D. Hanahan, and M. Wigler. 1980. Genetic and physical linkage of exogenous sequence in transformed cells. Cell 22: 309-317.

Pirrotta, V. 1986. Cloning Drosophila genes. In Drosophila, a practical approach (ed. D.B. Roberts), pp. 83-110. IRL Press, Oxford.

Posakony, J.W., J.A. Fischer, and T, Maniatis. 1986. Identification of DNA sequences required for the regulation of Drosophila alcohol dehydrogenase gene expression. Cold Spring Harbor Symp. Quant. Biol. 50: 515-520.

Rigby, P.W.J., M. Dieckmann, C. Rhodes, and P. Berg. 1977. Labelled deoxyribonucleic acids to high specific activity in vitro by nick translation with DNA polymerase I. J. Mol. Biol. 113: 237-251.

Robertson, H.M., C.R. Preston, R.W. Phillis, D.M. JohnsonSchiltz, W.K. Benz, and W.R. Engels. 1988. A stable source of P-element transposase in Drosophila melanogaster. Ge- netics 118: $461-470$.

Rozek, C.E. and N. Davidson. 1983. Drosophila has one myosin heavy-chain gene with three developmentally regulated transcripts. Cell 32: 23-34.

Rubin, G.M. and A.C. Spradling. 1983. Vectors for P-elementmediated gene transfer in Drosophila. Nucleic Acids Res. 11: $6341-6351$.

Rudkin, G.T. 1965. The relative mutabilities of DNA in regions of the X chromosome of Drosophila melanogaster. Genetics 52: $665-681$.

Rudkin, G.T. 1972. Replication in polytene chromosomes. In Results and problems in cell differentiation led. W. Beermann|, vol. 4, pp. 59. Springer-Verlag, New York.

Sanger, F., S. Nicklen, and A.R. Coulson. 1977. DNA sequencing with chain-terminating inhibitors. Proc. Natl. Acad. Sci. 74: 5463-5467.

Southern, E. 1975. Detection of specific sequences among DNA fragments separated by gel electrophoresis. I. Mol. Biol 98: 503-517.

Spierer, P., A. Spierer, W. Bender, and S. Hogness. 1983. Molecular mapping of genetic and chromomeric units in Drosophila melanogaster. I. Mol. Biol. 168: 35-50.

Steller, H. and V. Pirrotta. 1986. P-transposons controlled by the heat shock promoter. Mol. Cell. Biol. 6: 1640-1649.

Steller, H., K.-F. Fischbach, and G.M. Rubin. 1987. disconnected: A locus required for neuronal pathway formation in the visual system of Drosophila. Cell 50: 1139-1153.

Tatchell, K., D.T. Chaleff, D. DeFeo-Jones, and E.M. Scolnick. 1984. Requirement of either of a pair of ras-related genes of Saccharomyces cerevisiae for spore viability. Nature 309: $523-527$.

Voelker, R.A., G.B. Wisely, S.-M. Huang, and H. Gyurkovics. 1985. Genetic and molecular variation in the RpII215 region of Drosophila melanogaster. Mol. Gen. Genet. 201: 437445.

Wieschaus, E., C. Nüsslein-Vohard, and G. Jürgens. 1984. Mutations affecting the pattern of the larval cuticle in Drosophila melanogaster III. Zygotic loci on the X-chromosome and the fourth chromosome. Wilhelm Roux's Arch. Dev. Biol. 193: 296-307.

Wilson, C., H.J. Bellen, R.K. Pearson, C.J. O'Kane, Y. Engström, G. Gibson, U. Grossniklaus, and W.J. Gehring. 1990. The little blue book. Drosophila Inform. Serv. 69 (in press.)

Zipursky, S.L., T.R. Venkatesh, and S. Benzer. 1985. From monoclonal antibody to gene for a neuron-specific glycoprotein in Drosophila. Proc. Natl. Acad. Sci. 82: 1855-1859. 


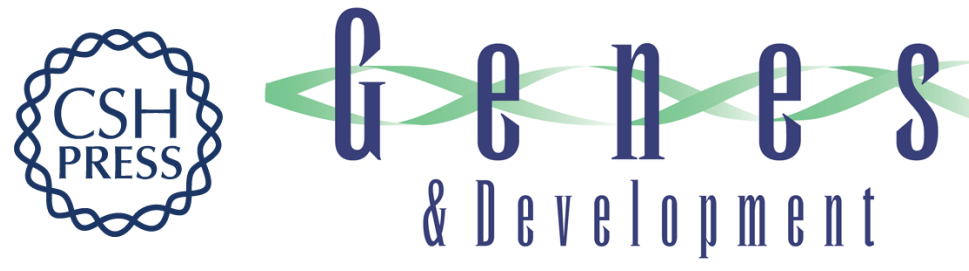

\section{P-element-mediated enhancer detection: an efficient method for isolating and characterizing developmentally regulated genes in Drosophila.}

C Wilson, R K Pearson, $\mathrm{H} J$ Bellen, et al.

Genes Dev. 1989, 3:

Access the most recent version at doi:10.1101/gad.3.9.1301

References This article cites 48 articles, 20 of which can be accessed free at: http://genesdev.cshlp.org/content/3/9/1301.full.html\#ref-list-1

License

Email Alerting Service

Receive free email alerts when new articles cite this article - sign up in the box at the top right corner of the article or click here.

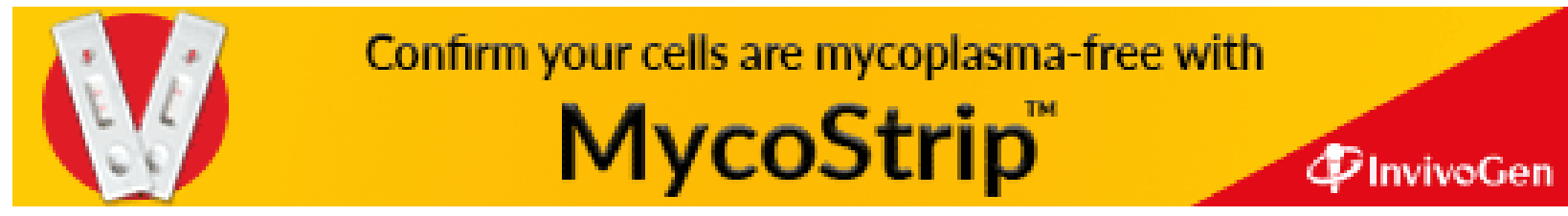

